\title{
Study Legal Sponsor
}

National Cancer Institute

\section{Source}

National Cancer Institute. Study Legal Sponsor. NCI Thesaurus. Code C93478.

A sponsor that initiates the investig ation and is legally responsible for the study. 